\title{
The approach of political ecology as an alternative method to overcome socio-economic problems
}

\author{
Husnul Isa Harahap * dan Rosmery \\ Department of Political Science Universitas Sumatera Utara (USU), Kota Medan, Indonesia
}

\begin{abstract}
There are many efforts that has been done by the society to meet their economic needs. But there are often obstacles in the processes. One among them an expensive food's prices. Is political ecological approach can be used as an alternative method to overcome the society social issues? It reliability is based on three reasons. First, so far the political ecological approach has a very small negative side effect for humans therefore it is environmentally friendly. Secondly, in some cases it is easy to develop at an affordable cost. Third, the results achieved is more valuable. The political ecological approach is thus a viable method developed and promoted through public policy.
\end{abstract}

\section{Introduction}

Society and socioeconomic problems are two unseparated things. When there is society there will be socioeconomic problems. This is because humans involve in both social and economics. Humans live in a society with primary (basic) and other needs that must be fulfilled. Socioeconomic problem arises when human has difficulty in fulfilling their need and when they finally use many methods to fulfil their needs.

One of the way to fulfil their needs is by increasing their economic income. As a result, it takes several efforts to be involved in the economic process. As for example, they breed animals to be sold for money, grows plants to increase their income. Economically, with the increased amount of income, their need would be fulfilled.

Nature resources can be used in economic processes. However, it cannot limit or prevent human behaviour against it. As a result, human beings use these natural resources to resolve their economic problems, even in ways that can cause harm to nature and for humans. In the end humans enter the circle of problems, especially when humans cannot resolve their economic problems and at the same time nature also loses resources to fulfil human needs.

Solution to the socioeconomic problems of human beings is done with an approach that is not environmentally based. Hence this solution often creates new problems. The result of the solution is often a controversy relationship between mankind and nature. For example, fertilizers are made to fertilize the soil. As an impact of this act, there will be degrading

\footnotetext{
* Corresponding author: husnul.harahap@usu.ac.id
} 
upon the soil fertility. These condition makes us depend on a fertilizer. Similarly, among farmers, where they use inorganic to feed. As a result, people who are farming do not succeed to get the maximum profit cut of their efforts. The cause of the problem is that, cost of fertilizer is more expensive.

In accordance with this background, overall this study reveals three fundamental problems. First, environmental problems are lack of attention. Second, the old approach is not able to overcome environmental problems. Third, this old approach is also unable to overcome socio-economic problems. The question that arises, is there any alternative approach to solve this problem? This study offers a political ecology approach as an answer to this question. The political ecology approach is an alternative model for resolving socioeconomic issues.

\section{Method}

The Method that used in this study is qualitative. Data collection methods applied are literature and document studies. Literature materials and documents used are available both in online and offline. Method of analysis is with political ecology approach. According to Tim Forsyth who reviewed Piers Blaike's view that "environmental analysis and policy can be reframed towards addressing the problems of socially vulnerable people" [1].

The main idea on this study is elaborate relationship between environmental sustainability with the society welfare and vice versa. The society's efforts to increase their economic income can be done without damaging the environment, or efforts to utilize the available resources naturally turn out to increase the income of the society. Thus, environmental and social problems can be analysed simultaneously.

\section{Alternative Model}

Political ecology is a social science that emerged in the 1980s. This science is transdisciplinary. One of the most important things is that, it is between nature and the social world. As a transdisciplinary, it sometimes combines social science and the natural sciences. According to Paul Elliott Little "Some of the most important recent transformations in the ecological paradigm are the development of trans disciplinary syntheses between the social and natural sciences ..." [2].

This approach sees that socioeconomic and environmental problems can be solved simultaneously. The socioeconomic problem arises as a result of the process of producing certain subject that humans are distracted by the high cost, followed by the condition where the environment is contaminated. As a conclusion, the socioeconomic problem comes with environmental problems. In the case of farmers, there are cases where the price of poultry feed causes low profit to the farmer at the harvest time. Whereas the expensive poultry feed on the other hand pollutes the environment. The political ecology as an alternative method shows that if the utilization on natural resources be used to the fullest extent the social and environment issues will solve simultaneously.

For example an integrated farming system which integrated rice fields, ducks to support an organic farming [3]. In the early stages of this system succeed to decrease the dependence of farmer to chemical materials. The chemical materials is made from the fertilizer. Even though this fertilizer contains chemical materials, the cost is still expensive. This system has a potential to increase the income because the cost of the organic farming products are more expensive than an organic one. Therefore, this system can be develop easier. 
From a socioeconomic perspective there are several problems arising from the use of chemicals in agriculture through fertilizers. According to I Wayan Supartha the first “...terjadi penurunan produktivitas lahan pertanian akibat praktek-praktek penggunaan sarana produksi (pupuk dan pestisida) buatan yang berlebihan" [sic.][4] [“...there is a decrease in agricultural productivity due to the practice of excessive use of production of fertilizers and pesticides".] Secondly "adanya ketakutan masyarakat konsumen terhadap produk-produk pertanian (konvensional) yang sarat dengan kandungan residu pestisida" [sic.][4] [“...there is a fear of society towards agricultural products (conventional) which are loaded with pesticide residue content".]

Another example of the alternative methods of ecological approach is integrated farming in Pekanbaru, Riau Province. According to the results of a study conducted by L. Siswati and R. Nizar with the theme of Integrated Farming System for Horticulture and Beef Cattle to Improve Farmer Income, there are several benefits that had been felt by the society. According to them there are three main benefits. The first benefit is empty land that can be productive. Average land area of 0.3 ha, cattle ownership of four to five animals [5].

The second benefit is integrated agriculture crop of horticulture and cattle can increase farmer's income. Horticulture income per planting period is 9,731,147 rupiah per year. Revenue from livestock business 9.345.328 rupiah -per year. The forms of mixed farming include vegetables, cattle and fruits such as papaya, melon, jackfruit, and sapodilla. It appears that this has a socioeconomic value.

The third benefit is this technique can reduce the use of fertilizer. As we know fertilizer are not good for the environment. Siswati explained that “...penggunaan pupuk anorganik yang selama ini digunakan oleh petani apabila digunakan terus menerus dapat menyebabkan dampak negativ terhadap lingkungan, antara lain tanah menjadi padat akibat efek rekat (glueing effect) terutama pada pupk ammonium, bereaksi masam dan bila tercuci samapai ke air tanah bila air dikomsumsi dapat menimbulkan penyakit" [sic.][5] ["...the use of inorganic fertilizer that used by farmers continuously can cause negative impact to the environment such as, the soil becomes solid due to the gluing effect especially the ammonium fertilizer, react sour when it is washed to the ground, thus the water consumed can cause disease".] So this proved to be environmentally friendly.

Based on all the example, it appears that the alternative method provides considerable benefits, not only for humans but also for the environment. But the question is, if indeed the ecological approach is more profitable, why there are still many people who approaches methods that are not based on the environment? There are three explanations related to this. First, political ecology is an underdeveloped approach in the society. This has consequences many people didn't know about it.

Second, an organic models have been applied in society long time ago, thus it is easier to apply them, and supported by product advertisement that intense to socialize it. The equipment are available. The expert on it is easier to find. Similarly, the example that had been applied, is quite easy to find. Meanwhile, the approach of political ecology requires practice and integrated system. When this system is applied there will still be a doubt, such as will this system work? This is the sign that states there are many people who still do not fully believe in this system. So it can be summarized that there are still a problems of nonexistent view of the system.

Third, the approach of political ecology actually requires an active role from the government. Therefore, the question is whether the government program is already based on political ecology approach to solve socioeconomic problems? In general, in many countries the political ecological approach has not become an issue of concern to the governments. In Indonesia there are several local governments that support this alternative method, such as in Bali. 
Another question is, does the general government have or have not felt the need to popularize this method? Of course there is an opportunity to make it happen. But the thing that needs to underline is, in the end the course is not always enough without seriousness in the program's process. The success and failure of this program is strongly influenced by the seriousness of the implementation of the political ecology approach. Seriousness will obviously affect the results because without any seriousness the results achieved will not be maximized.

\section{Conclusion}

One of the causes of the emergence of social problems is the condition where society does not has the ability to fulfil the needs of the economy. This is inseparable from the fact that many people are trying to improve their economic needs. But some are successful and some are not. The lack of success is one of them based on circumstances that are considered not supportive. This situation arises from the choice of a very "instant" approach method to overcome the economic problem.

The political ecology approach provides an alternative method for resolving the social issues. It is based on three reasons. First, so far the ecological approach has a very small negative side effect for humans therefore it is environmentally friendly. Second, in some cases it is easy to develop with an affordable cost. Third, the results achieved have a more valuable quality. In some cases this alternative method has been successfully implemented. The political ecology approach is thus a viable method developed and promoted through public policy.

\section{References}

1. T. Forsyth, Political Ecology and the Epistemology of Social Justice, Geoforum, 39, no. 2, pp. 756-764, Mar. (2008).

2. P. E. Little, Political Ecology as Ethnography: a Theoretical and Methodological Guide, Horizontes Antropologicos 3, (2007).

3. M. C. T. Bintang, P. Marbun, and Yunilas, Pertanian Terpadu Sistem Integrasi Ladang, Sawah dan Ternak Itik untuk Mendukung Pertanian Organik, Jurnal Abdimas TALENTA, 1, no. 1, pp. 97-100, (2016).

4. I. W. Supartha and N. L. Kartini, Konsep dan Strategi Pengembangan Pertanian Organik di Bali, presented at the Seminar Regional Pertanian Organik dan Prospek Pengembangannya di Bali, Fakultas Pertanian UNUD Denpasar, (2001).

5. R. Nizar and L. Siswati, Model Pertanian Terpadu Tanaman Hortikultura dan Ternak Sapi untuk Meningkatkan Pendapatan Petani, Jurnal Peternakan Indonesia 14, no. 2 , pp. 379-384, Jun. 2012. 